\title{
Phenotypic Identification of Clostridium Perfringens Associated With Necrotic Enteritis of Broiler Chickens in Sharkia Governorate
}

Enany M.E. *; Ammar, A.M.** and Mona, A. Maghwery***and Noha,

\section{A. Gamal.}

*Bacteriology, Immunology and Mycology Department, Fac. of Vet. Med., Suez Canal University **Bacteriology, Mycology and Immunology Department, Fac. of Vet. Med., Zagazig University .***Anaerobic Unit, Bacteriology Research Department, Animal Health Research Institute, Dokki, Giza.

\begin{abstract}
A total of 314 samples of liver and intestinal loop were collected from broiler chickens suffering from diarrhea during 2013-2014 .The tissue samples were examined for the prevelance of C.perfringens revealed 91 (66.93\%) of them were toxinogenic and $44(31.06 \%)$ non toxinogenic isolates .One hundered and thirty two samples were positive for Clostridium perfringens typing by intradermal inoculation in guinea pig. The higher incidence of C.perfringens was recorded in winter $(53.12 \%-57.5 \%)$ followed by autumn (50\%) then summer (32.60\%-37.93\%) and the lower incidence was recorded in spring (30\%-31.25\%). The incidence of C.perfringens from intestinal samples was(65.85\%-58.66\%)and liver samples was(21.95\%-21.33\%). The most effective antibiotic was recommended for treatment of necrotic enteritis were amoxicillin, Ampicillin, Piperacillin, ceftraxione, cefruxime, Cefotaxime which was applied by sensitivity test to 91 isolates of toxinogenic Clostridium perfringens. Our study recorded that there is the isolation rate of Clostridium perfringens from intestine was exteremly higher than liver samples and ranged from $(58.66 \%-65.85 \%)$ and $(21.95 \%-21.33)$,respectively that subtyped into type A 76 (57.57\%) and typeD 15 (11.36\%).
\end{abstract}

\section{Introduction}

Necrotic enteritis(NE),is one of the most important infectious disease affecting poultry, where the birds lose the ability to digest nutrients from feed (Cooper et al, 2009). According to the production of four major toxins alpha,beta, epsilon and iota. C. perfringens is classified into five types A,B,C,D and E (Cato et al, 1986). All types of C.perfringens produced a multifunctional phospholipase leathal toxin called alpha toxin (Songer, 1996). The understanding of disease progression of necrotic 
enteritis has been very difficult and usually challening due to its complexity, many clostridial species can be normal inhabitants of the gut ,making it difficult to determine these role in virulenc (Cooper et al, 2013). As a normal inhabitantin the intestinal tract of healthy birds activated C.perfringens when several predisposing factors as coccidiosis ,high protein in ration,food stuff rich in Zinc (Baba et al, 1992a), poor hygenic condition Fram and Bickfordn (1986) and Jakson et al (2003) were included.They are required to elicit the clinical signs and lesions of NE (Kaldhusdal et al, 1999). The most widely used method for detection clostridial toxins is the mice neutralization test (Stern and Batty, 1975). So, the aim of this study was isolation,identification, typing of $C$. perfringens and Serological identification of $C$. perfringens strains by toxin- antitoxin neutralization test.This work was studying the in vitro antibiotic sensitivity pattern of clostridial species to different chemotherapeutic agents as amoxicillin, Ampicillin, Piperacillin, ceftraxione, cefruxime, Cefotaxime, chloramphenicol, erythromycin trimethoprim+ sulphamethazole, tetracycline, Deoxycycline, lincomycin, enrofloxacin, and Streptomycin in order to check the highly potent ones recommended to eliminate such conditions

\section{Material and methods samples}

A total number of 157 intestinal and 157 liver samples were collected from 75 flocks have broiler chickens suffering from diarrhea,ruffled feathers and stunted growth respectively during 20132014. The recent dead broiler were affecting part of intestine showed ballowing ,thining ,velvety appearance and liver showed necrosis some of diseased chicken were suffering from coccidiosis the samples were collected from private flocks of different ages(20-50 days) in sharkia governorat . The collected birds represented (75)flocks.

\section{Bacteriological examination}

Each sample was inoculated onto tubes of freshly prepared cooked meat medium (CMM) then incubated anaerobically at $37 \mathrm{c}$ for 48h. A loopful from each one was streaked onto the surface of $10 \%$ sheep blood agar with neomycin sulphate $(200 \mathrm{mg} / \mathrm{ml})$. The plates were incubated anaerobically at $37 \mathrm{c}$ for $48 \mathrm{hr}$ the suspected colonies of $C$. perfringens were picked up and examined for morphological, Microscopical appearance Wilson and Miles (1975). and biochemical characters according to Koneman et al (1992). Activity of lecithinase of C.perfringens alpha toxin agler's test by half antitoxin plate as described by Smith and Holdeman (1968). The toxins of $C$. perfringens were typed by dermonecrotic test in 
albino guinea pigs (Bullen, 1952). The results were interpreted by the degree of the dermonecrotic reaction (Stern and Batty, 1975). The neutralization tests were performed by using toxin antitoxin of different types of C.perfrenges in albino guinea pig (Smith and Holdeman, 1968) by using diagnostic C.perfringens antitoxin typeA,B, C,D and E (Burroguns, Welcome, Beckenham, London, England)

Sensitivity of C.perfringens isolates to chemotheraputic agents

the disc diffusion method was used on a pure sub cultures from 91 isolates of clostridia causing necrotic enteritis of broilers as described by Koneman et al (1992). The antibiotic discs were purchased from oxoid LTD, london , england. Briefly, one milliliter of $24 \mathrm{hrs}$ broth culure was spread on the surface of muller hinton agar (oxoid No337). Antibiotic disc were placed on the surface of seeded agar plates and were incubated anaerobically at 37c for $24 \mathrm{hrs}$ the sensitivity was judged according to the diameter of inhibition zone arround each disc and compared with standered figures.

\section{Results}

\section{Incidence of $\mathrm{C}$. perfringensin}

The Incidence of C. perfringensin among different flocks during (2013-2014)in Sharkia Governorate was ulseratted in tables $(1,2)$ and figure $(1,2)$ respectively.
Identification of $C$. perfringens isolates:

Regarding to traditional methods for identification of C.perfringens recovered from diseased broilers, the obtained results revealed that C.perfringens is Gram positive short plumb rarely sporulated and non motile bacilli (Photo 2). The C.perfringens revealed double zone of haemolysis on sheep blood agar with neomycin sulphate (200 $\mu \mathrm{g} / \mathrm{ml}$ ) (Photo 1).

All the isolates were fermentative to different sugars as glucose, sucrose ,lactose,mannose and maltose with production of acid and gases, catalase, oxidase, gelatin liquefiers, litmus milk positive, and indole tests negative.

Nagler's test (lecithinase activity) represented the action of $C$. perfringens alpha toxin on lecithin of egg yolk onto enriched egg yolk agar medium which appeared as pearly opalescence zone surround the colonies while this reaction was inhibited by $C$. perfringens alpha toxin antiserum (Photo 3)

C.perfringens isolates recovered from diseased broilers were identified by dermonecrotic reactions in albino guinea pigs into 91 strains were toxigenic $(68.93 \%)$ (76 type A, 15 type D) and 41 strains were non toxigenic with an incidence of $31.06 \%$ respectively (Table 5 ) photo(4).

Sensitivity of $C$. perfringens isolates derived from diseased broilers to different antimicrobial agents 
C.perfringens was highly sensitive to amoxicillin, Ampicillin, C.perfringens isolates were Piperacillin, ceftraxione, cefruxime, Cefotaxime, Fuscidic acid and Bacitracin. while chloramphenicol and erythromycin were of moderate effect. On the other hand

Table (1): Incidence of C. perfringens from broiler chickens in 2013

\begin{tabular}{|c|c|c|c|c|c|c|c|c|c|}
\hline \multirow{2}{*}{$\frac{n}{\frac{O}{U}}$} & \multirow{2}{*}{.$\Xi$} & \multicolumn{3}{|c|}{ No. of samples } & \multicolumn{3}{|c|}{ No. of positive sample } & \multirow{2}{*}{$\begin{array}{c}\text { No. of }+ \text { ve } \\
\text { samples in } \\
\text { different } \\
\text { seasons }\end{array}$} & \multirow[b]{2}{*}{$\%$} \\
\hline & & Int. & L. & Total & Int. & L. & Total & & \\
\hline 1 & 25 & 2 & 2 & 4 & 1 & 1 & 2 & \multirow{6}{*}{$\begin{array}{c}\text { Spring } \\
\text { (10) }\end{array}$} & \multirow{6}{*}{$31.25 \%$} \\
\hline 2 & 20 & 3 & 3 & 6 & 2 & - & 2 & & \\
\hline 3 & 26 & 4 & 4 & 8 & 2 & 1 & 3 & & \\
\hline 4 & 30 & 2 & 2 & 4 & 1 & - & 1 & & \\
\hline 5 & 32 & 1 & 1 & 2 & - & - & & & \\
\hline 6 & 19 & 4 & 4 & 8 & 1 & 1 & 2 & & \\
\hline 7 & 22 & 3 & 3 & 6 & 3 & - & 3 & \multirow{10}{*}{$\begin{array}{l}\text { Summer } \\
\text { (22) }\end{array}$} & \multirow{10}{*}{$37.93 \%$} \\
\hline 8 & 45 & 2 & 2 & 4 & - & - & & & \\
\hline 9 & 33 & 4 & 4 & 8 & 3 & 1 & 4 & & \\
\hline 10 & 31 & 1 & 1 & 2 & 1 & - & 1 & & \\
\hline 11 & 25 & 2 & 2 & 4 & 2 & - & 2 & & \\
\hline 12 & 22 & 4 & 4 & 8 & 4 & 1 & 5 & & \\
\hline 13 & 37 & 2 & 2 & 4 & - & - & - & & \\
\hline 14 & 43 & 3 & 3 & 6 & 2 & 1 & 3 & & \\
\hline 15 & 36 & 5 & 5 & 10 & 2 & 1 & 3 & & \\
\hline 16 & 34 & 3 & 3 & 6 & - & 1 & 1 & & \\
\hline 17 & 29 & 1 & 1 & 2 & - & - & - & \multirow{8}{*}{$\begin{array}{l}\text { Autumn } \\
\text { (17) }\end{array}$} & \multirow{8}{*}{$50 \%$} \\
\hline 18 & 27 & 2 & 2 & 4 & 1 & 1 & 2 & & \\
\hline 19 & 21 & 3 & 3 & 6 & 3 & 1 & 4 & & \\
\hline 20 & 24 & 1 & 1 & 2 & 1 & 1 & 2 & & \\
\hline 21 & 22 & 1 & 1 & 2 & 2 & - & 2 & & \\
\hline 22 & 33 & 2 & 2 & 4 & - & 1 & 1 & & \\
\hline 23 & 49 & 5 & 5 & 10 & 3 & 1 & 4 & & \\
\hline 24 & 37 & 2 & 2 & 4 & 1 & 1 & 2 & & \\
\hline 25 & 27 & 3 & 3 & 6 & 2 & 1 & 3 & \multirow{9}{*}{$\begin{array}{c}\text { Winter } \\
(23)\end{array}$} & \multirow{9}{*}{$57.5 \%$} \\
\hline 26 & 24 & 2 & 2 & 4 & 2 & - & 2 & & \\
\hline 27 & 35 & 1 & 1 & 2 & - & - & & & \\
\hline 28 & 40 & 4 & 4 & 8 & 3 & 1 & 4 & & \\
\hline 29 & 23 & 2 & 2 & 4 & 3 & 1 & 4 & & \\
\hline 30 & 36 & 2 & 2 & 4 & 2 & 1 & 3 & & \\
\hline 31 & 27 & 3 & 3 & 6 & 3 & - & 3 & & \\
\hline 32 & 20 & 2 & 2 & 4 & 3 & - & 3 & & \\
\hline 33 & 22 & 1 & 1 & 2 & 1 & - & 1 & & \\
\hline $\begin{array}{c}\text { Tot } \\
\text { al }\end{array}$ & & 82 & 82 & 164 & $\begin{array}{c}54 \\
(65.85 \%\end{array}$ & $\begin{array}{c}18 \\
(21.95 \%\end{array}$ & 72 & 72 & $43.90 \%$ \\
\hline
\end{tabular}

No.: Number

Int.: Intestine resistance to trimethoprim+ sulphamethazole , tetracycline, Deoxycycline, lincomycin, clindamycin, enrofloxacin, and Streptomycin (table 6)

No.: Number

L.: Liver 
Table (2): Incidence of C. perfringens from broiler chickens in 2014

\begin{tabular}{|c|c|c|c|c|c|c|c|c|c|}
\hline \multirow{2}{*}{$\begin{array}{l}\frac{\tilde{\theta}}{U} \\
\frac{\theta}{x}\end{array}$} & \multirow{2}{*}{ 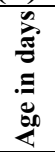 } & \multicolumn{3}{|c|}{ No. of samples } & \multicolumn{3}{|c|}{ No. of positive sample } & \multirow{2}{*}{$\begin{array}{l}\text { No. of }+ \text { ve } \\
\text { samples in } \\
\text { different } \\
\text { seasons }\end{array}$} & \multirow{2}{*}{$\%$} \\
\hline & & Int. & L. & Total & Int. & L. & Total & & \\
\hline 1 & 25 & 1 & 1 & 2 & 1 & - & 1 & \multirow{11}{*}{$\begin{array}{c}\text { Spring } \\
\text { (12) }\end{array}$} & \multirow{11}{*}{$30 \%$} \\
\hline 2 & 22 & 3 & 3 & 6 & 1 & 1 & 2 & & \\
\hline 3 & 36 & 2 & 2 & 4 & 1 & - & 1 & & \\
\hline 4 & 33 & 1 & 1 & 2 & - & - & - & & \\
\hline 5 & 20 & 3 & 3 & 6 & 1 & 1 & 2 & & \\
\hline 6 & 25 & 2 & 2 & 4 & 1 & - & 1 & & \\
\hline 7 & 40 & 1 & 1 & 2 & - & - & - & & \\
\hline 8 & 37 & 3 & 3 & 6 & 1 & 1 & 2 & & \\
\hline 9 & 51 & 2 & 2 & 4 & 1 & 1 & 2 & & \\
\hline 10 & 29 & 1 & 1 & 2 & 1 & - & 1 & & \\
\hline 11 & 32 & 1 & 1 & 2 & - & - & - & & \\
\hline 12 & 27 & 4 & 4 & 8 & 2 & 1 & 3 & \multirow{9}{*}{$\begin{array}{c}\text { Summer } \\
\text { (15) }\end{array}$} & \multirow{9}{*}{$32.60 \%$} \\
\hline 13 & 40 & 1 & 1 & 2 & 1 & - & 1 & & \\
\hline 14 & 42 & 2 & 2 & 4 & 2 & - & 2 & & \\
\hline 15 & 21 & 1 & 1 & 2 & - & 1 & 1 & & \\
\hline 16 & 41 & 2 & 2 & 4 & 2 & - & 2 & & \\
\hline 17 & 35 & 1 & 1 & 2 & 1 & - & 1 & & \\
\hline 18 & 36 & 1 & 1 & 2 & 1 & - & 1 & & \\
\hline 19 & 50 & 2 & 2 & 4 & 1 & 1 & 2 & & \\
\hline 20 & 42 & 2 & 2 & 4 & 1 & 1 & 2 & & \\
\hline 21 & 46 & 3 & 3 & 6 & 2 & 1 & 3 & \multirow{13}{*}{$\begin{array}{l}\text { Autumn } \\
\text { (16) }\end{array}$} & \multirow{13}{*}{$50 \%$} \\
\hline 22 & 28 & 1 & 1 & 2 & - & - & - & & \\
\hline 23 & 27 & 2 & 2 & 4 & 1 & - & 1 & & \\
\hline 24 & 33 & 1 & 1 & 2 & - & - & - & & \\
\hline 25 & 28 & 1 & 1 & 2 & 1 & - & 1 & & \\
\hline 26 & 20 & 3 & 3 & 6 & 2 & - & 2 & & \\
\hline 27 & 34 & 1 & 1 & 2 & - & - & - & & \\
\hline 28 & 32 & 2 & 2 & 4 & 1 & - & 1 & & \\
\hline 29 & 30 & 3 & 3 & 6 & 2 & 1 & 3 & & \\
\hline 30 & 23 & 1 & 1 & 2 & - & - & - & & \\
\hline 31 & 25 & 1 & 1 & 2 & 1 & - & 1 & & \\
\hline 32 & 31 & 1 & 1 & 2 & - & - & - & & \\
\hline 33 & 23 & 3 & 3 & 6 & 3 & 1 & 4 & & \\
\hline 34 & 27 & 1 & 1 & 2 & 1 & - & 1 & \multirow{9}{*}{$\begin{array}{c}\text { Winter } \\
(17)\end{array}$} & \multirow[t]{9}{*}{$53.12 \%$} \\
\hline 35 & 20 & 1 & 1 & 2 & 2 & - & 2 & & \\
\hline 36 & 33 & 3 & 3 & 6 & 3 & 1 & 4 & & \\
\hline 37 & 44 & 1 & 1 & 2 & - & - & - & & \\
\hline 38 & 22 & 1 & 1 & 2 & 1 & - & 1 & & \\
\hline 39 & 23 & 4 & 4 & 8 & 3 & 2 & 5 & & \\
\hline 40 & 43 & 2 & 2 & 4 & 1 & - & 1 & & \\
\hline 41 & 22 & 1 & 1 & 2 & 1 & - & 1 & & \\
\hline 42 & 29 & 2 & 2 & 4 & 1 & 1 & 2 & & \\
\hline Total & & 75 & 75 & 150 & $\begin{array}{c}44 \\
(58.66 \%)\end{array}$ & $\begin{array}{c}16 \\
(21.33 \%)\end{array}$ & 60 & 60 & $40 \%$ \\
\hline
\end{tabular}




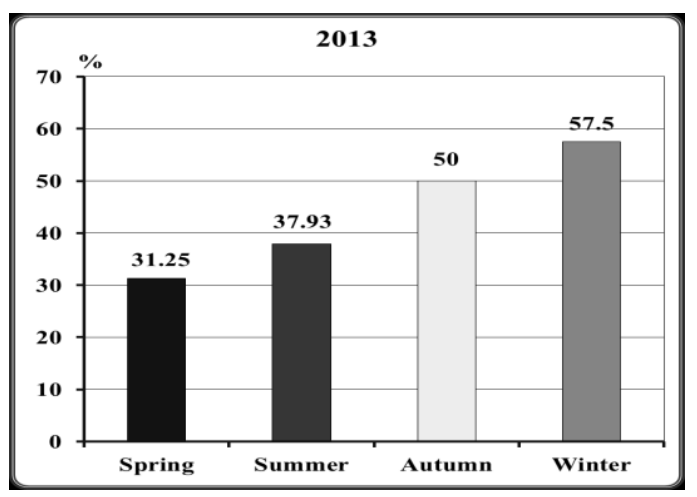

Fig. (1): Occurence of C. perfringens from broiler farms in 2013

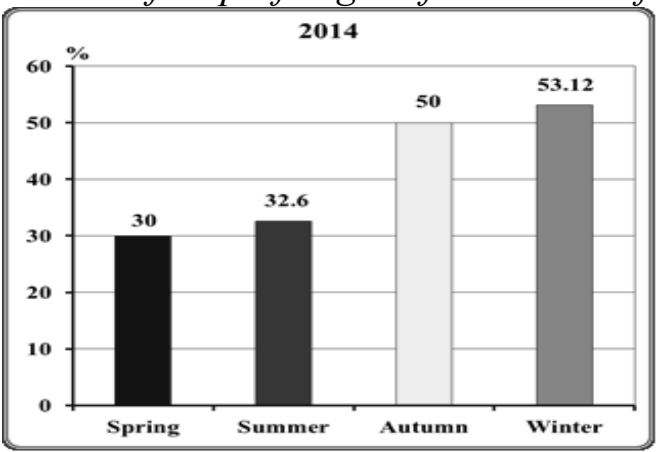

Fig. (2): Occurence of C. perfringens from broiler farms in 2014

Table (3) Recovery rate of C.perfringens isolates from broilers in relation to different ages 2013

\begin{tabular}{|c|c|c|c|}
\hline Age & $\begin{array}{c}\text { Number of } \\
\text { examined samples }\end{array}$ & $\begin{array}{c}\text { Number of +ve } \\
\text { samples }\end{array}$ & $\mathbf{\%}$ \\
\hline $\mathbf{2 0 - 3 0}$ days & 90 & 46 & 51.11 \\
\hline $\mathbf{3 0 - 4 0}$ days & 52 & 18 & 34.6 \\
\hline $\mathbf{4 0 - 5 0}$ days & 22 & 8 & 36.3 \\
\hline Total & 164 & 72 & 43.90 \\
\hline
\end{tabular}

Table (4): Recovery rate of C.perfringens isolates from broilers in relation to different ages 2014

\begin{tabular}{|c|c|c|c|}
\hline Age & $\begin{array}{c}\text { Number of } \\
\text { examined samples }\end{array}$ & $\begin{array}{c}\text { Number of +ve } \\
\text { samples }\end{array}$ & $\%$ \\
\hline 20-30 days & 80 & 35 & 43.75 \\
\hline $\mathbf{3 0 - 4 0}$ days & 34 & 10 & 29.41 \\
\hline 40-50 days & 36 & 15 & 41.66 \\
\hline Total & 150 & 60 & 40 \\
\hline
\end{tabular}



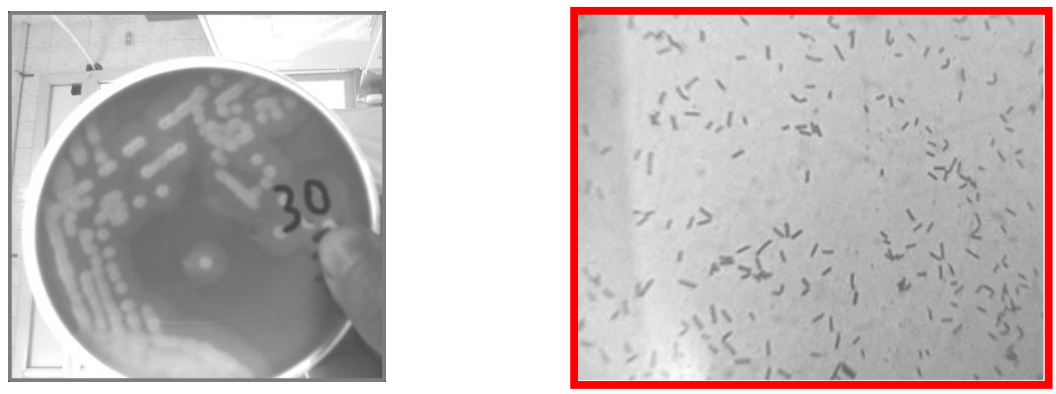

Photo (1): C. perfringens induced double zone of haemolysis onto neomycin sulphate sheep blood agar.

Photo (2): C.perfringens show Gram positive short bacilli stained with Gram's stain .

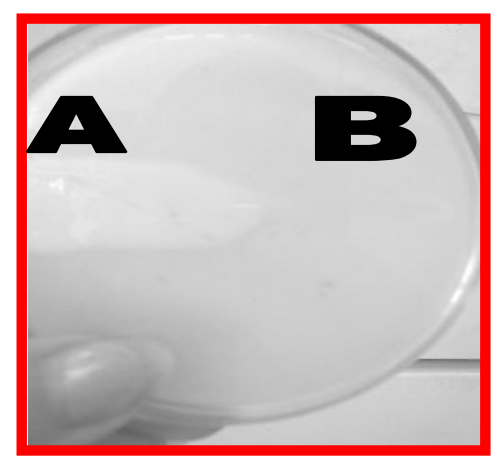

\section{Photo (3): Nagler's test}

A)C. perfringens gave opalescence appearance due to licithinase effect of alpha toxin On egg yolk agar medium

B) Neutriliation of C.perfringens $\alpha$-toxin by its specific antitoxin

Table (5): Typing of toxigenic C.perfringens isolates recovered from diseased broilers

\begin{tabular}{|c|c|c|c|c|c|c|c|}
\hline \multirow{3}{*}{$\begin{array}{c}\text { Number of } \\
\text { examined } \\
\text { ]samples }\end{array}$} & \multirow{3}{*}{$\begin{array}{l}\text { Number of } \\
\text { positive } \\
\text { samples }\end{array}$} & \multicolumn{6}{|c|}{ Types of C. Perfringens } \\
\hline & & \multicolumn{4}{|c|}{$\begin{array}{c}\text { Toxigenic isolates } \\
91(68.93 \%)\end{array}$} & \multicolumn{2}{|c|}{$\begin{array}{l}\text { Non-toxigenic } \\
\text { isolates }\end{array}$} \\
\hline & & & $\mathbf{A}$ & & D & Number & $\%$ \\
\hline 314 & 132 & 76 & $57.57 \%$ & 15 & $11.36 \%$ & 41 & 31.06 \\
\hline
\end{tabular}



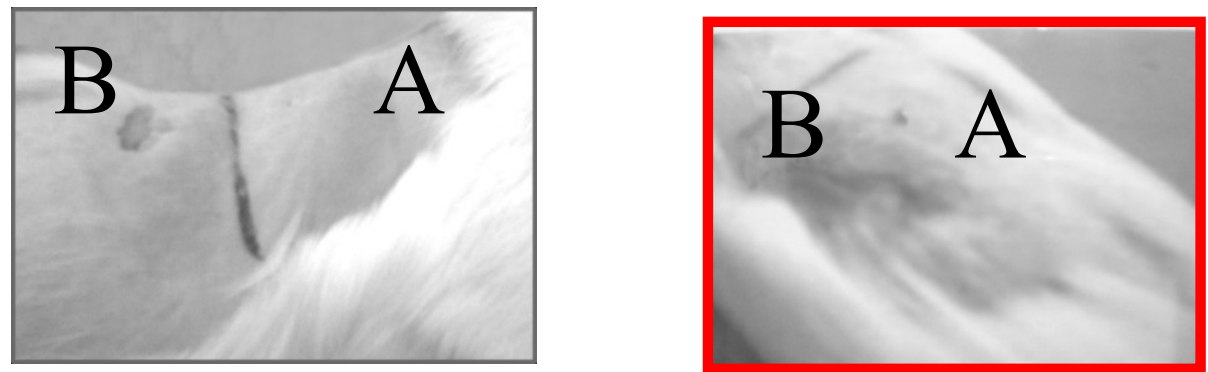

Photo (4): Dermonecrotic reaction used for typing of C.perfringens A and $D$.

(A) Alpha toxin shows an irregular area of yellowish green on the skin of albino guinea pig.

(B) Epsilon toxin produces a circular whitish green necrosis A few small of purplish haemorrhagic areas.

Photo (5): Toxin antitoxin neutralization test on the skin of albino guina pig (A) Action of C.perfringens alpha toxin on necrosis and the lesion tends to spread downward.

(B) Neutralization of C.perfringens alpha toxin with its specific antiserum.

Table (6): Sensitivity of C. perfringens isolates from diseased broilers to different antimicrobial agents

\begin{tabular}{|c|c|c|c|c|c|c|c|c|}
\hline $\begin{array}{c}\text { Antimicrobial } \\
\text { agents }\end{array}$ & Code & $\mathbf{R}$ & $\mathbf{I}$ & $\mathbf{S}$ & $\begin{array}{c}\text { Average } \\
\text { of Iz } \\
\text { (mm) }\end{array}$ & $\begin{array}{c}\text { No. of S } \\
\text { isolates / } \\
\text { total (91) }\end{array}$ & \% & A.A \\
\hline Amoxicillin & Ax 25 & $\leq 15$ & $16-22$ & $\geq 23$ & 24 & 82 & 90.10 & $\mathrm{~S}$ \\
\hline Ampicillin & AM10 & $\leq 13$ & $14-16$ & $\geq 17$ & 23 & 73 & 80.21 & $\mathrm{~S}$ \\
\hline Piperacillin & PRL100 & $\leq 17$ & $18-20$ & $\geq 21$ & 25 & 79 & 86.81 & $\mathrm{~S}$ \\
\hline Ceftraxione & CRO30 & $\leq 14$ & $15-22$ & $\geq 23$ & 28 & 79 & 86.81 & $\mathrm{~S}$ \\
\hline Cefruxime & CXM 30 & $\leq 14$ & $15-22$ & $\geq 23$ & 27 & 82 & 90.10 & $\mathrm{~S}$ \\
\hline Cefotaxime & CTX 30 & $\leq 14$ & $15-22$ & $\geq 23$ & 30 & 88 & 96.70 & $\mathrm{~S}$ \\
\hline Doxycycline & DO 30 & 12 & $13-15$ & $16 \geq$ & 5 & 12 & 13.18 & $\mathrm{R}$ \\
\hline Tetracycline & TE 30 & $\leq 14$ & $15-18$ & $\geq 19$ & 3 & 16 & 17.58 & $\mathrm{R}$ \\
\hline Bacitracin & B 10 & $\leq 8$ & $9-12$ & $\geq 13$ & 27 & 77 & 84.61 & $\mathrm{~S}$ \\
\hline Erythromycin & E 15 & $\leq 13$ & $14-17$ & $\geq 18$ & 16 & 33 & 36.26 & $\mathrm{~S}$ \\
\hline Lincomycin & L 2 & $\leq 13$ & $14-21$ & $\geq 22$ & 4 & 10 & 10.98 & $\mathrm{R}$ \\
\hline Clindamycin & DA 2 & $\leq 11$ & $12-20$ & $\geq 21$ & 8 & 23 & 25.27 & $\mathrm{R}$ \\
\hline $\begin{array}{c}\text { Trimethoprim- } \\
\text { sulphamethoxazol }\end{array}$ & SXT30 & $\leq 10$ & $11-15$ & $\geq 16$ & 3 & 10 & 10.98 & $\mathrm{R}$ \\
\hline Chloramphenicol & C 30 & $\leq 12$ & $13-17$ & $\geq 18$ & 13 & 31 & 34.06 & $\mathrm{~S}$ \\
\hline Streptomycin & S 10 & $\leq 11$ & $12-14$ & $\geq 15$ & 5 & 22 & 24,17 & $\mathrm{R}$ \\
\hline Enrofloxacin & ENR 5 & \multicolumn{1}{|c|}{} & & 6 & 15 & 16.48 & $\mathrm{R}$ \\
\hline Fuscidic acid & FA 10 & $\leq 12$ & $13-20$ & $\geq 21$ & 24 & 69 & 75.82 & $\mathrm{~S}$ \\
\hline
\end{tabular}

\section{Iz:Inhibitory zone}

No.:Number $\quad S$ :Sensitive $I$ : Intermediate sensitive $R$ : Resistant $\%:$ Percentage of sensitive isolates A.A.:Antibiogram activity 


\section{Disscusion}

Clostridium perfringens plays an important role in the development of NE disease in broiler chickens (Broussard et al, 1986). Signs of necrotic enteritis involved reluctant to move, diarrhea and decrease in appetite (Ficken and Wages, 1997). Atotal of 314 intestinal and liver samples were collected from 75 broiler flocks in different seasons and ages from Sharkia Governorate.Table(1,2).The

incidence of $C$. perfringens in this study was $43.90 \%$ in 2013 and $40 \%$ in 2014.Comparable percentage of C.perfringens isolates were reported in Egypt by Abd El-Salam (2000), Abd El-Gwad and Abd El-Kader (2001) and Ahmed (2010) who reported incidence of $50 \%, 51.4 \%$, $48.5 \%, \quad 40 \%, 44.4 \%$ and $45 \%$ ,respectively, from different localities in Egypt.

However higher occurance was recorded by Dosoky (1990) and Afify and Nasr (2009) who succeded in detect C.perfringens in chicken with $79 \%$ and $75.55 \%$ respectively.In the present study the isolation rate of C.perfringens from diseased chickens in 2013 and 2014 was $65.85 \%$ and $58.66 \%$,respectively in intestine and $21.95 \%$ and $21.33 \%$, respectively in liver.There are rise in incidence of C.perfringens from intestinal samples compared with liver samples and this could be indicated that C.perfringens is predisposing factor to necrotic enteritis and normal inhabitant in intestine
(Silva et al, 2009). These results were nearly similar to the results obtained by El-Refay (1999), Ahmed (2010) and Ali (2010) who reported that the incidence of $C$. perfringens isolation from intestine was $33.3 \%, 53.08 \%$ and $41.7 \%$ respectively. Also, the results coinside with Awad (2012) who stated that the incidence of C.perfringens isolated from intestine and liver was $47.4 \%$ and $12.3 \%$, respectively. Concerning the incidence of $C$. perfringens in different seasons, the results in the present study revealed that the higher incidence of C.perfringens was noted in winter $(57.5 \%$ in 2013 and $53.12 \%$ in 2014$)$ autumn $(50 \%$ in 2013 and $50 \%$ in 2014) then summer (37.93\%) in 2013 and $32.60 \%$ in 2014) and the lower incidence was recorded in spring $(31.25 \%$ in 20013 and $30 \%$ in 2014). These results due to adverse environmental condition in cold seasons. These results agree with that reported by Kaldhusdal and Skjerve (1996) and Ahmed (2010) who reported high incidence in cold seasons (October to March) and low incidence in worm season (April to September), while disagree with that reported by, Berinier et al. (1974a) and Cygan and Nawak (1974) who reported high incidence in July, August, September and October (summer and autumn).

Johansson (2006) who stated that, in 2-4 weeks old chickens necrotic enteritis occurs as an acute clinical disease and causing high mortality. 
The relationship between the incidence of C.perfringens dietary factors ,coccidiosis, and bad hygienic condition shown in the incidence is little pit lower at 30-40 days and increased in 40-50 days and this may due to increase the protein content in the diet. These results agree with that reported by Knarreborg et al. (2002).

C.perfringens recovered from diseased broiler identified by microscopical examination, culture characteristics, biochemical tests and Nagler's test (Smith and Holdeman, 1968); Peter et al, 1986;Han et al, 1997; Vaikosen and Muller, 2001 and Assis et al, 2002). isolates were identified by dermonecrotic reactions of $C$. perfringens isolates in albino guinea pigs classified into toxigenic (68.93\%) [type A $57.57 \%$, type D was $11.36 \%$ ] and non toxigenic $(31.06 \%)$.These results were nearly in agreement with the result obtained by Songer and Dale (2005) who typed C.perfringens as toxigenic and non toxigenic strains in an incidence of $36.1 \%$ and $15.3 \%$ respectively.

In this work ,toxin antitoxin neutralization test on the skin of albino guinea pigs was done by using specific antitoxin to identify the toxigenic strains of C.perfringens recovered from diseased broilers. These results are in agreement with Songer and Dale (2005).

In the present work, sensitivity of C.perfringens isolates to antimicrobial agents in vitro was studied, as shown in table (6) it was noted that $C$. perfringens isolates were highly sensitive $(80-96 \%)$ to amoxicillin, ampicillin, pipracillin, ceftraxione, cefruxime and Bacitracin followed by fuscidic acid similar results were reported by Jansen and (Jansen and Bermmelgaard, 1988; Traub, 1990; Tansuphasiri et al, 2005 and Silva et al, 2009) who reported highly susceptible of C.perfringens to amoxicillin, ,ceftraxione,cefruxime and Bacitracin. while chloramphenicol and erythromycin were of moderate effect $(40 \%)$, On the other hand C.perfringens isolates were resistance to trimethoprim+sulphamethazole tetracycline, Deoxycycline, lincomycin, clindamycin, streptomycin, ,tobramycin, enrofloxacin streptomycin and kanamycin(9.09$13.2 \%)$. These findings are in general agreement with those of (Abdel-Rhman et al, 2006; Ali, 2010; Mohammed, 2013 and Farag et al, 2013). These results are in accordance with Johansson et al (2004) and Silva et al (2009) they reported that C.perfringens isolates were resistant to tetracycline. Also, disagree with Afify and Nasr (2004) Who indicated that enroflxacin, and erythromycin were highly effective against colestridum isolates.This study was cocluded that $C$. perfringens plays a serious role in necrotic enteritis through 
proliferation in the intestine and production of several exotoxins . Higher incidence of $C$. perfringens was recorded in winter in age of 20:30day that attributed to environmental stress and unhygienic conditions then 40:50day and the intestine appeared to be the most common site for isolation of $C$. perfringens followed by liver. Type A was the most predominant one. C.perfringens strains recovered from chicken suffering from necrotic enteritis in broilers indicated that C.perfringens was highly sensitive to amoxicillin, Ampicillin, Piperacillin, ceftraxione, cefruxime, Cefotaxime, Fuscidic acid and Bacitracin. while chloramphenicol and erythromycin were of moderate effect . On the other hand C.perfringens isolates were resistance to trimethoprim+sulphamethazole , tetracycline, Deoxycycline, lincomycin, clindamycin, enrofloxacin, and Streptomycin.

\section{Reerence}

Abd El-Gwad A.M. and Abd ElKader H.A. (2001): The occurrence of Clostridium perfringens in the intestine of broiler chickens in Assiut Governorate. Assiut Univ. Bullet. Environ. Res., 4 (2).

Abd El-Rahman A.A., Moustafa F.A. and Hamd N.A. (2006): Detection of the prevalence and pathogenicity of $C$. perfringens and $C$. spiroform associated diarrhea in rabbits. Assiut Vet. Med. J., 52 (108): 321-335.
Abd El-Salam W.M. (2000): Microbiological studies on anaerobic microorganisms causing diseases in poultry. M.V.Sc. Thesis, (Microbiology),Fac. Vet. Med., Cairo University.

Afify, Mona M. and Nasr, Eman M. (2004): A study on clostridium species in chickens and turkeys with special reference to the efficacy of ELISA for detection of Clostridium perfringens toxin. Mansoura, Vet. Med. J. (11-24)

Afify, Mona M. and Nasr, Eman M. (2009): The use of western Blot Technique for toxino types of Clostridium perfringens isolated from rabbits with enteric disease) Egypt. Vet. Med. Assoc.69(3):59-73.

Ahmed S. A. (2010): Incidence and rapid detection of Clostridium perfringens infection in broilers.

M.V.Sc., Thesis, (Microbiology), Fac. Vet. Med., Zagazig University.

Ali,Dina mostafa (2010): Phenotyping and genotyping characterization of Clostridium perfringens in poultry. M.V.Sc., Thesis,(Microbiology), Fac. Vet. Med., Cairo University.

Assis, R. A.; Uzal, F.A.; Santana, F. J. F.; Dias, L. D. and Parreiras, P. M.(2002): Isolation of C. perfringens type $\mathrm{D}$ from a suckling calf with ulcerative abomasitis. Arch. Med. Vet., 2: 287 292

Awad,Amal N. (2012) :Studies on Clostridum perfringens in laying hens ,M,V,SC,Thesis (Microbiology), Fac. Vet. Med., Cairo University

Baba E., Fuller A.L., Gillbert J.M., Thayer S.G. and McDougald L.R. (1992a): Effects of Eimeria brnetti infection and dilatory zinc on experimental induction of necrotic enteritis in broiler chickens. Avian Dis., 36: 59-62. 
Bernier G., Filion R., Malo R. and Phaneuf J.B. (1974a): Necrotic enteritis in broilers. I. Clinocopathological aspect. Can. J. Comp. Med., 38 (3): 280-285.

Broussard, C.T; Hofacare, C.L.; Page, R.K. and Fletcher, O.J.(1986):

Necrotic enteritis in cage reared commercial layer pullets" Avian Dis., 30(3):617-619

Cato E.P., George W.L. and Finegold S.M. (1986): Genus Clostridium Prazmowski 1880, 23 AL. In Bergey's Manual of Systematic Bacteriology. Edited by Sneath, P.H.A. Mair, N.S.. Sharpe M.E, Williams, J.G. Holt. and Wilkins.Baltimore, USA.1179-1182. pp.

Cooper K.K., Songer J.G. and Uzal F.A.(2013):Diagnostic clostridial enteric disease in poultry .Journal of Veterinary Diagnostic Investigation, Published online .

Cooper K.K., Trinh H.T. and Songer J.G. (2009): Immunization with recombinant alpha toxin partially protects broiler chicks against experimental challenge with Clostridium perfringens. Vet. Microbiol.133:92-97.

Cygan and Nowak J. (1974): Necrotic enteritis in chicks. II. Toxigenic properties of Clostridum perfringens type "C" strains and experimental infection of Japanese quail. Medycyna Weterynaryjina, 30 (5): 262-265.

Dosoky R.M. (1990): The role of the environment in the occurrence of clostridia infection among fowls. Assiut Vet. Med. J., 24 (47): 165-171.

\section{El-Refaey}

T.M.

(1999):

Bacteriological studies on Clostridium microorganisms in poultry. Thesis, M.V.Sc., (Microbiology) Fac.Vet. Med., Cairo University.
Farag, Eman F. , Eskander, Dalia K. and Abd-El-Hamid T.M.(2013) Some bacteriological studies on enteritis in pet animals.Animal Health Research Journal , 1(4): 69-80.

Ficken M.D. and Wages D.(1997): Necrotic enteritis .In: disease of poultry,ed. Saif YM,Calnek B.W.,Barnes et al.,10 ${ }^{\text {th }}$ ed .,pp.261-264 Lowa State University Press .London.

Frame D.D. and Bicford A.A. (1986): An outbreak of coccidiosis and necrotic enteritis in 16 week old cage reared layer replacement pullets. Avian Dis., 30: 601-602.

Han, S. Y.; Sang, u.; Kyoung, Y. P. and Yong, H. P. (1997): Molecular typing and Epidemiological survey of prevalence of C.perfringens. by multiplex PCR. Journal of Clinical Microbiology.228-232.

Jackson M.E., Anderson D.M., Methis G.F. and Fodge D.W. (2003): Beneficial effect of flmannanase feed enzyme on performance of chickens challenged with Eimeria species and Clostridium perfringense. Avian Dis., 47:579-763.

Jansen J.E. and Bermmelgaard A.(1988): Determination of susceptibility of anaerobic bacteria to beta lactam antibiotics by a tablet diffusion test. APMIS.96(5):464-470.

Johansson A. (2006): C. perfringens the causal agent of necrotic enteritis in poultery Ph.D. Thesis, Biomedical Sciences, Fac. Vet. Med. Swedish Univ.

Johansson C.; Greko, B.; Engstrom, E. and Karisson M.(2004): Antimicrobial susceptibility of Swedish, Norwegian and Danish isolates of Clostridium perfringens from poultry and distribution of tetracycline resistance genes. Vet . Microbiol., 99(3-4): 251-257. 
Kaldhusdal

Hofshogen,M.,Lovland,

A.,Langstrand,

H.

M., perfringens strains isolated from

broiler chickens. Braz. J. Microbiol.,

40: 261-263.

Redhead,K.(1999): Necrotic enteritis challenge models with broiler chicken raised on litter.Evolution of precondition,Clostridium perfringens strains and outcome variables.FEMS microbial .Med. Immunol.,24:337-343.

Kaldhusdal M. and Skjerve E. (1996): Association between cereal content in the diet and incidence of necrotic enteritis in broiler chickens in Norway., Prevent. Vet. Med., 28: 1-16.

Knarreborg A., Engberg R.M. Jensen B.B. and Jensen S.K. (2002): Quantities determination of bile salt hydrolase activity in bacteria isolated from small intestine of chicken. Applied and Environmental Microbiology, 68: 6425-6428.

Koneman E.W., Allen S.D., Dowell V.R. and Summers H.W. (1992): Colour atlas and text book of diagnostic microbiology. $4^{\text {nd }}$ Ed. J. B. Lippin Cott, New York, London.

Mohammed,Amira S. (2013): ):

Molecular studies on Clostridium

Perfringens resistant to tetracycline group. Ph. D. Thesis,

(Microbiology),Fac.Vet. Med, Cairo University. .

Peter, H. A.; Nicholas, S.; Elisabeth, S. and John, G.(1986) Bergey`s

Manua Systemic Bacteriology, Vol.2, Williams and Wilkins.

Silva R.O.S., Salvarani F.M., Assis R.A., Martins N.R.S., Pires P.S. and Lobato F.C.F. (2009): Antimicrobial susceptibility of Clostridium
Smith L.D.S. and Holdeman (1968):

The pathogenic anaerobic bacteria. $1^{\text {st }}$ Ed., Charles Thomas Publisher, USA, 201-255.

Songer J.G. and Dale W.M. (2005): Clostridial abomasitis in calves: case report and review of the literature. Anaerobe, (11): 290-294.

Songer J.G. (1996): Clostridial enteric diseases of demostic animals. Clin. Microbial. Rev., 9: 216-234.

Stern M. and Batty I. (1975): Pathogenic Clostridia. Butter Worth, London, Boston.

Tansuphasiri, V.; Matra W. and Sangsuk L.(2005): Antimicrobial resistance of Clostridium perfringens isolated from various sources in Thailand. SE Asian Trop. Med.Pub. Health, 36:954-961.

Traub W.H. (1990): Comparative in vitro bacterial activity of 24 antimicrobial drugs against Clostridium perfringens. Chemotherapy,36(2):127135.

Vaikosen, E.S. and Muller, W. (2001): Evaluating biochemical tests for isolation / identification of C.perfringensin faecal samples of small ruminants in Nigeria.Bulletin of Animal Health and Production in Africa ، 49 (4): 244- 248.

Wilson, G. S. and Miles, A. A. (1975): Principles of bacteriology, virology and immunology. $6^{\text {th }} \mathrm{Ed}$., vol. 1 and vol. 11, Baltimore: Williams and Wilkins. 


\section{التوصيف الظاهرى للكولستريديم بيرفيرنجينز المصاحبة للنزلات المعوية

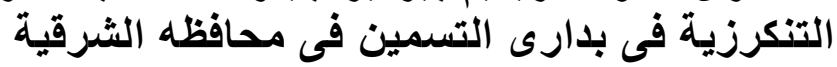

عحه السيد عنانى*_احمد عحم عمار**_منى مغاورى عفيفى***- نهى جمال عبد الرحمن.

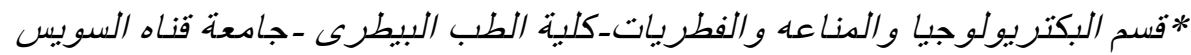

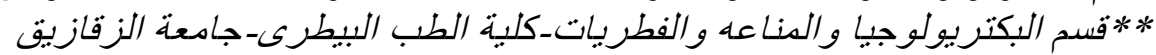

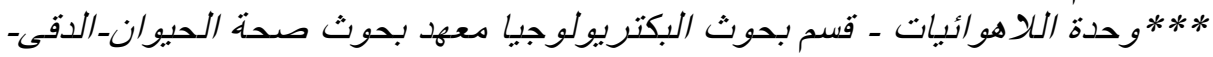
الجبيزه

تم اجر اء هذة الدراسة على ع اس عينة من الامعاء و الكبد جمعت من بدارى تسمين تعانى من اسهال

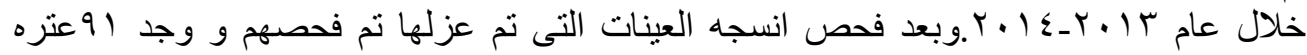

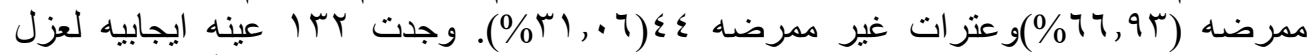

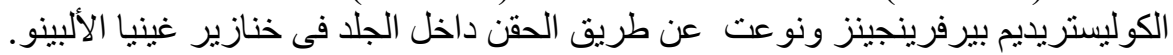



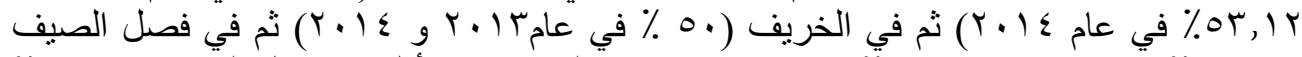

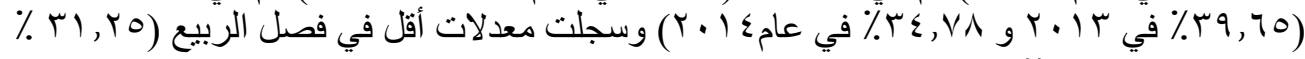

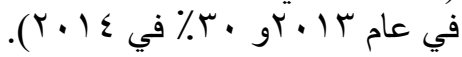

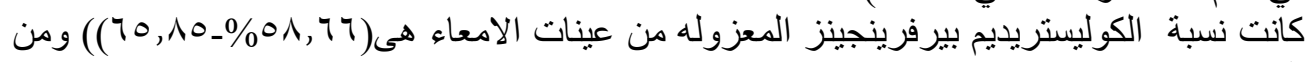

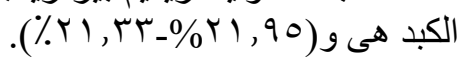

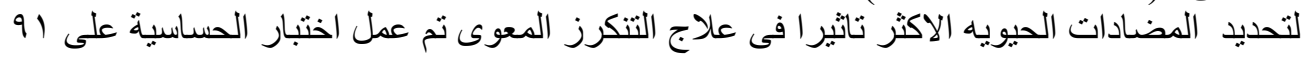

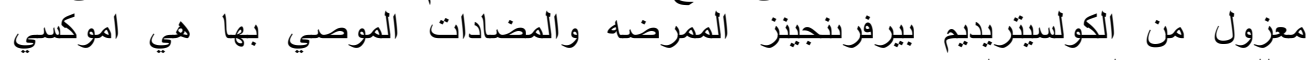

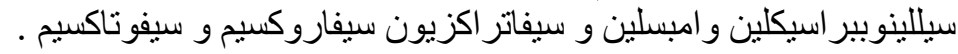

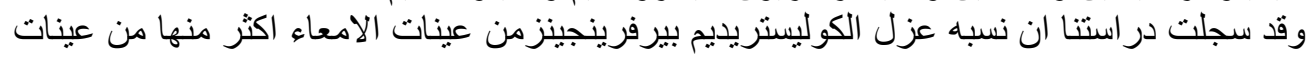

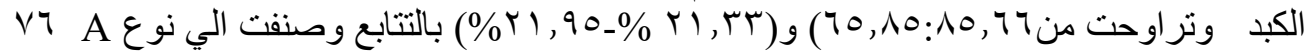

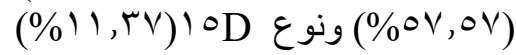

